Boston University School of Law

Scholarly Commons at Boston University School of Law

Faculty Scholarship

2002

Protecting the Endangered Human: Toward an International

Treaty Prohibiting Cloning and Inheritable Alterations

George J. Annas

Follow this and additional works at: https://scholarship.law.bu.edu/faculty_scholarship

Part of the Health Law and Policy Commons, and the International Law Commons 


\title{
Protecting the Endangered Human: Toward an International Treaty Prohibiting Cloning and Inheritable Alterations
}

\author{
George J. Annas, Lori B. Andrews and Rosario M. Isasit
}

\section{INTRODUCTION}

We humans tend to worry first about our own happiness, then about our families, then about our communities. In times of great stress, such as war or natural disaster, we may focus temporarily on our country but we rarely think about Earth as a whole or the human species as a whole. This narrow perspective, perhaps best exemplified by the American consumer, has led to the environmental degradation of our planet, a grossly widening gap in living standards between rich and poor people and nations and a scientific research agenda that focuses almost exclusively on the needs and desires of the wealthy few. Reversing the worldwide trends toward market-based atomization and increasing indifference to the suffering of others will require a human rights focus, forged by the development of what Vaclav Havel has termed a "species consciousness." 1

In this Article we discuss human cloning and inheritable genetic alterations from the human species perspective, and suggest language for a proposed international "Convention of the Preservation of the Human Species" that would outlaw all efforts

+ George J. Annas is the Edward R. Utley Professor and Chair of the Health Law Department, Boston University School of Public Health, Professor of SocioMedical Sciences and Community Medicine, Boston University School of Medicine, Professor of Law, Boston University School of Law, and cofounder of Global Lawyers and Physicians. A.B., Harvard College (1967); J.D., Harvard Law School (1970), M.P.H., Harvard School of Public Health (1972).

Lori B. Andrews is Distinguished Professor of Law, Chicago-Kent College of Law, and Director, Institute for Science, Law, and Technology, Illinois Institute of Technology. B.A., Yale College (1975); J.D., Yale Law School (1978).

Rosario M. Isasi is the Health Law and Bioethics Fellow, Health Law Department, Boston University School of Public Health. B.A., Pontificia Universidad Catolica del Peru (1987); J.D., Pontificia Universidad Catolica del Peru (1992); M.P.H., Boston University School of Public Health (2002).

( 2002 George J. Annas, Lori B. Andrews and Rosario M. Isasi. All rights reserved.

1 "We still don't know how to put morality ahead of politics, science and economy. We are still incapable of understanding that the only genume backbone of all our actions, if they are to be moral, is responsibility-responsibility to something higher than my family, my country, my company, my success." Vaclav Havel, Excerpts from Czech Chief's Address to Congress, N.Y. TIMES, Feb. 22, 1990. at A14. See also AMARTYA SEN, DEVELOPMENT AS FREEDOM (1999); George J. Annas, Mapping the Juman Genome and the Meaning of Monster Mythology, 39 EMORY L.J. 629, 661-64 (1990). 
to initiate a pregnancy by using either intentionally modified genetic material or human replication cloning, such as through somatic cell nuclear transfer. We summarize international legal action in these areas over the past five years, relate these actions to arguments for and against a treaty and conclude with an action plan.

\section{HUMAN RIGHTS AND THE HUMAN SPECIES}

The development of the atomic bomb not only presented to the world for the first time the prospect of total annihilation, but also, paradoxically, led to a renewed emphasis on the "nuclear family," complete with its personal bomb shelter. The conclusion of World War II (with the dropping of the only two atomic bombs ever used in war) led to the recognition that world wars were now suicidal to the entire species and to the formation of the United Nations with the primary goal of preventing such wars. ${ }^{2}$ Prevention, of course, must be based on the recognition that all humans are fundamentally the same, rather than on an emphasis on our differences. In the aftermath of the Cuban missile crisis, the closest the world has ever come to nuclear war, President John F. Kennedy, in an address to the former Soviet Union, underscored the necessity for recognizing similarities for our survival:

[L]et us not be blind to our differences, but let us also direct attention to our common interests and the means by which those differences can be resolved .... For, in the final analysis, our most basic common link is that we all inhabit this small planet. We all breathe the same air. We all cherish our children's future. And we are all mortal. ${ }^{3}$

That we are all fundamentally the same, all human, all with the same dignity and rights, is at the core of the most important document to come out of World War II, the Universal Declaration of Human Rights, and the two treaties that followed it (together known as the "International Bill of Rights"). ${ }^{4}$ The recognition of universal human rights, based on human dignity and equality as well as the principle of nondiscrimination, is fundamental to the development of a species consciousness. As Daniel Lev of Human Rights Watch/Asia said in 1993, shortly before the Vienna Human Rights Conference:

Whatever else may separate them, human beings belong to a single biological species, the simplest and most fundamental commonality before which the significance of human differences quickly fades. . . . We are all capable, in exactly the same ways, of feeling pain, hunger,

2 See The Charter of the United Nations: A Commentary 49 (Bruno Simma el al. eds., 1995)

3 Commencement Address at American University in Washington, PUB. PAPERS 459, 462 (June 10, 1963). President George W. Bush echoed Kennedy's words almost forty years later: All fathers and mothers, in all societies, want their children to be educated and live free from poverty and violence. No people on earth yeam to be oppressed or aspire to servitude or eagerly await the midnight knock of the secret police. . . America will lead by defending liberty and justice because they are right and true and unchanging for all people everywhere.

No nation owns these aspirations and no nation is exempt from them. We have no intention of imposing our culture, but America will always stand firm for the nonnegotiable demands of human dignity: the rule of law; limits on the power of the state; respect for women; private property; free speech; equal justice; and religious tolerance.

Address Before a Joint Session of the Congress on the State of the Union, 38 WeEkLY COMP. PRES. DOC. 133, 138 (Jan. 29, 2002).

4 See Henry 3. Steiner \& PhILIP Alston, International Human Rights in CONTEXT: LAW, POLITICS, MORALS 137-4I (2d ed. 2000). 
and a hundred kinds of deprivation. Consequently, people nowhere routinely concede that those with enough power to do so ought to be able to kill, torture, imprison, and generally abuse others. . . The idea of universal human rights shares the recognition of one common humanity, and provides a minimum solution to deal with its miseries. ${ }^{5}$

Membership in the human species is central to the meaning and enforcement of human rights, and respect for basic human rights is essential for the survival of the human species. The development of the concept of "crimes against humanity" was a milestone for universalizing human rights in that it recognized that there were certain actions, such as slavery and genocide, that implicated the welfare of the entire species and therefore merited universal condemnation. 6 Nuclear weapons were immediately seen as a technology that required international control, as extreme genetic manipulations like cloning and inheritable genetic alterations have come to be seen today. In fact, cloning and inheritable genetic alterations can be seen as crimes against humanity of a unique sort: they are techniques that can alter the essence of humanity itself (and thus threaten to change the foundation of human rights) by taking human evolution into our own hands and directing it toward the development of a new species, sometimes termed the "posthuman."7 It may be that speciesaltering techniques, like cloning and inheritable genetic modifications, could provide benefits to the human species in extraordinary circumstances. For example, asexual genetic replication could potentially save humans from extinction if all humans were rendered sterile by some catastrophic event. But no such necessity currently exists or is on the horizon.

As a baseline, if we take human rights and democracy seriously, a decision to alter a fundamental characteristic in the definition of "human" should not be made by any individual or corporation without wide discussion among all members of the affected population. No individual scientist or corporation has the moral warrant to redesign humans (any more than any individual scientist or corporation has the moral warrant to design a new, lethal virus or bacteria that could kill large numbers of humans). Altering the human species is an issue that directly concerns all of us, and should only be decided democratically, by a body that is representative of everyone on the planet. ${ }^{8}$ It is the most important decision we will ever make.

The environmental movement has adopted the precautioi:ary principle to help stem the tide of environmental alterations that are detrimental to humans. One version of this principle holds that "when an activity raises threats of harm to human health or the environment ... the proponent of that activity, rather than the public, should bear the burden of proof [that the activity is more likely to be beneficial than harmful]." 9 The only way to shift the burden of proof is to outlaw potentially lethal

5 Quoted in Mary ann Glendon, a World Made New: Eleanor Roosevelt and the UNIVERSAL DECLARATION OF HUMAN RIGHTS 223 (2001).

6 See generally M. CHERIf Bassiouni, CRIMES AGaINSt humanity IN INTERNational. CRIMINAL LAW (1992) (exploring the history and evolution c. "crimes against humanity"). See also George J. Annas, The Man on the Moon. Immoriality, and Other Millennial Myths: The Prospects and Perils of Human Genetic Engineering, 49 EMORY L.J. 753, 778-80 (2600) (discussing the possibility of species-alteration becoming a new category of "crimes against humanity").

7 See, e.g., Francis fukuyama, OUr Posthuman future: Consequences of the BIOTECHNOLOGY REVOLUTION (2002). Of course, these actions have not yet been recognized as crimes against humanity or any other type of international crime, and this is one reason why some still see these activities as legitimate.

8 Obviously, the only current candidate is the United Nations.

9 Protecting Public Health and the Environment: IMplementing the Precautionary PRINCIPLE 354 (Carolyn Raffensperger \& Joel A. Tickner eds., 1999). 
activities, thus requiring proponents to change the law before proceeding. This can be done nation by nation, but can only be effective (because scientists and laboratories can move from country to country) by an internationally-enforceable ban. The actual text of a treaty banning human replicative cloning and inheritable modifications will be the subject of debate. We suggest the following language, obviously subject to future negotiations as well as added details, as a basis for going forward:

\section{Convention on the Preservation of the Human Species}

The Parties to this Convention,

Noting that the Charter of the United Nations affirms human rights, based on the dignity and worth of the human person and on equal rights of all persons;

Noting that the Universal Declaration of Human Rights affirms the right of every person not to be discriminated against;

Realizing that human dignity and human rights derive from our common humanity;

Noting the increased power of genetic science, which opens up vast prospects for improving health, but also has the power to diminish humanity fundamentally by producing a child through human cloning or by intentionally producing an inheritable genetic change;

Concerned that human cloning, which for the first time would produce children with predetermined genotypes, rather than novel genotypes, might cause these children to be deprived of their human rights;

Concerned that by altering fundamental human characteristics to the extent of possibly producing a new human species or subspecies, genetic science will cause the resulting persons to be treated unequally or deprived of their human rights;

Recognizing the history of abuses of human rights in the name of genetic science;

Believing that no individual, nation or corporation has the moral or legal warrant to engage in species-altering procedures, including cloning and genetic alteration of reproductive cells or embryos for the creation of a child;

Believing that the creation of a new species or subspecies of humans could easily lead to genocide or slavery; and

Stressing the need for global cooperation to prevent the misuse of genetic science in ways that undermine human dignity and human rights;

Have agreed on the following:

Article 1

Parties shall take all reasonable action, including the adoption of criminal laws, to prohibit anyone from initiating or attempting to initiate a human pregnancy or other form of gestation using embryos or reproductive cells which have undergone intentional inheritable genetic modification.

\section{Article 2}

Parties shall take all reasonable action, including the adoption of criminal laws, to prohibit anyone from utilizing somatic cell nuclear transfer or any other cloning technique for the purpose of initiating or attempting to initiate a human pregnancy or other form of gestation. 


\section{Article 3}

Parties shall implement systems of national oversight through legislation, executive order, decree or other mechanism to regulate facilities engaged in assisted human reproduction or otherwise using human gametes or embryos for experimental or clinical purposes to ensure that such facilities meet informed consent, safety, and ethical standards.

Article 4

A Conference of the Parties and a Secretariat shall be established to oversee implementation of this Convention.

\section{Article 5}

Reservations to this Convention are not permitted.

\section{Article 6}

For the purpose of this Convention, the term "somatic cell nuclear transfer" shall mean transferring the nucleus of a human somatic cell into an ovum or oocyte. "Somatic cell" shall mean any cell of a human embryo, fetus, child or adult, other than a reproductive cell. "Embryo" shall include a fertilized egg, zygote (including a blastomere and blastocyst) and preembryo. "Reproductive cell" shall mean a human gamete and its precursors. ${ }^{10}$

10 This proposed Convention is the product of many people, including the participants at a September 21-22, 2001 conference at Boston University on "Beyond Cloning: Protecting Humanity from Species-Altering Procedures." The treaty language was the subject of a roundtable that concluded the conference. The authors, together with others, most especially Patricia Baird and Alexander Morgan Capron, had drafted language to be considered at the conference, and revised it after the conference based on the discussion that occurred there and comments on the draft by others.

The original draft also included the following codicil to encourage individual countries to examine broader issues as well:

\section{ISSUES FOR NATIONS TO CONSIDER IN FURTHERANCE OF THE CONVENTION} ON THE PRESERVATION OF THE HUMAN SPECIES

In the course of discussions about the Convention on the Preservation of the Human Species, countries may desire to expand the provisions to deal in greater detail with other matters. Perhaps there will be a desire to add a moratorium on the creation of cloned human embryos for research. It may also be thought useful to include provisions that deal more comprehensively with assisted reproduction and life-science patents. Such provisions could take into consideration the following issues:

\section{Assisted Human Reproduction}

\section{Potential Regulation:}

The regulation of the practice of assisted human reproduction could include such provisions as requirements of a license for any healthcare professional who or healthcare facility that:

- Facilitates assisted human reproduction, e.g., via donor insemination or in vitro fertilization;

- Undertakes research or treatment using an in vitro embryo;

- Collects, stores, transfers, destroys, imports or exports sperm, ova or in vitro embryos for reproduction or research purposes; or

- Undertakes genetic screening on an ex utero embryo.

The regulation of the practice of assisted human reproduction could also include provisions to ensure:

- Free and informed consent of prospective parents and gamete donors as a prerequisite to the use of the techniques;

- Quality assurance and proficiency testing for labs;

- Reporting to a governmental entity the outcomes (including births per attempt and data about morbidity and mortality of the resulting children for the first five years) and 
Perhaps the most difficult challenge in implementing this treaty is setting up the monitoring and enforcement mechanisms. Article Four would have to address these in detail. Although the specifics are beyond the scope of this article, some general comments are needed. Monitoring and compliance bodies must be broadly representative, possess authority to oversee activities related to human cloning and

\footnotetext{
disclosure to the public of this information;

- Non-misleading advertising (to the extent that advertising is permitted at all); and

- Confidentiality of individually identifiable health information.
}

Other prohibitions beyond those on human cloning and germline intervention might include bans on:

- Extracorporeal gestation of a human being;

- Transfer of a human embryo into an animal;

- Creation of embryos solely for research purposes; or

- Transplanting reproductive material (including gametes, ovaries or testes) from animals into humans.

\section{Gene Patents}

The purpose of the patent system is to encourage innovation and the development of products by providin: the holder of a patent with a twenty-year monopoly over the use of an invention. Patenting genes runs counter to this purpose because gene patents are stifing innovation and impeding access to genetic diagnostic and treatment technologies. Many researchers who are searching for genes that predispose individuals to diseases are reluctant to share information and tissue samples with other researchers because they want to discover the gene themselves and to reap the financial rewards of discovery. These rewards can be high. For example, one particular gene patent in the United States is worth $\$ 1.5$ billion annually.

Once a gene is discovered, the patent holder can prevent any doctor or laboratory from even checking a person's body to see if he or she has a mutation of the gene. Altematively, the patent holder can collect a very high royalty from the doctors and laboratories that examine the gene. The patent holder can even stop any use of the patented gene. One patent holder, for example, will not permit the use of its gene in prenatal screening because of the controversy surrounding abortion. Another patent holder, a major European pharmaceutical company, will not allow anyone to use its patented gene to develop a test which shows which patients will benefit from one of the company's drugs and which will not. Another biotechnology company has a patent on the genetic sequence of a particular infectious disease and is stopping another company from instituting inexpensive public health screening to determine if people are infected.

On the other hand, patent holders themselves may encourage premature adoption of genetic diagnostic tests and unsafe efforts at gene transfer experiments to benefit the patent holder rather than patients or research subjects. Moreover, special issues are raised in the case of patenting human tissue, including the ethical and legal propriety of ownership of one person's genetic information by another.

\section{Potential regulation:}

No patents shall be granted on human genes, parts of human genes or unaltered products of human genes, nor on the genes of bacteria, viruses or other infectious agents that cause disease in humans.

Work on a national regulatory scheme for the new reproductive technologies will, of course, be most relevant to countries that have an in-vitro fertilization (IVF) industry. We also believe that the best existing guidance for approaching such regulation is contained in the final report of Canada's Royal Commission on New Reproductive Technologies. I Patricia Baird, Proceed with Care: FINAL REPORT OF THE ROYAL COMMISSION ON NEW REPRODUCTIVE TECHNOLOGIES, 564-76 (1993). Also, to the extent that a country wants to proceed with research cloning (e.g., for the purpose of making stem cells or studying embryonic growth), regulation of the infertility industry will be needed to prevent a cloned embryo from being implanted in a woman's uterus. Such regulation could include, for example, the prohibition of freezing cloned embryos, and the prohibition of any physician or embryologist involved in IVF from making or possessing a cloned embryo. 
human genetic modification, and be able to enforce bans by announcing and denouncing potential violators. Moreover, we believe the commission (and the countries themselves) should support, through the Convention and through their national criminal laws, the establishment of two new international crimes: initiation of a pregnancy to create a human clone and initiation of a pregnancy using a genetically-altered embryo. 11

\section{AN INTERNATIONAL CONVENTION: WHY NOW?}

Five years after the announcement of the cloning of Dolly the sheep it is time to ask not if cloning and inheritable alterations should be regulated, but how. Had a five-year moratorium for further thought and discussion been placed on cloning humans, as the National Bioethics Advisory Commission (NBAC) recommended in 1997, for example, the time would now have expired.12 What new have we learned in the last five years?

First virtually every scientist in the world with an opinion believes it is unsafe to attempt a human pregnancy with a cloned embryo. ${ }^{13}$ This is, for example, the unanimous conclusion of a 2002 report from the U.S. National Academy of Sciences, which recommended that human "reproductive" cloning be outlawed in the United States following a study that included the viewpoints of the only two scientists in the world who publicly advocate human cloning today. ${ }^{14}$ Although scientists seldom like

11 While we believe these crimes should be subject to the jurisdiction of the Intemational Criminal Court, this may not be possible in the near future, and it is more important to establish them as intemational crimes than to broaden the definition of "crimes against humanity" as it applies to the International Criminal Court at this time.

12 NAT'L Bioethics Advisory COMM'N, Cloning HUMAN BEINGS 109 (1997), available at http://bioethics.georgetown.edu/nbac/pubs.html.

13 For example, during the 1998 debate on cloning in the U.S. Senate, more than sixteen scientific and medical organizations, including the American Society of Reproductive Medicine and the Federation of American Societies for Experimental Biology (which includes more than sixteen scientific and medical organizations), believed that there should be a moratorium on the creation of humans by cloning. See 144 CONG. REC. S434-38 (1998); 144 CONG. REC. S661 (1998). None of these organizations has since changed their position. See, e.g., Press Release, AM. SOC'Y REPRODUCTIVE MED., ASRM Statement on Atlempts at Human Cloning (Apr. 5, 2002) ("[W]e caution policy makers not to be rushed into approving over-reaching legislation that will criminalize valid scientific and medical research and the therapies they might lead to.") available at http://www.asrm.org/Media/Press/cloningstatement4-02; Letter from Carl B. Feldbaum, President, Biotechnology Ind. Org., to President George W. Bush (Feb. 1, 2002) ("The current moratorium on cloning humans should remain until our nation has had time to fully explore the impact of such cloning."), available at http://www.bio.org/bioethics/cloning letter bush.html. See also Rudolf Jaenisch \& Ian Wilmut, Don't Clone Humans!, 291 SCIENCE 2552 (2001) ("We believe attempts to clone human beings at a time when the scientific issues of nuclear cloning have not been clarified are dangerous and irresponsible."); Editorial, Reasons to be Cloned, 414 NATURE 567 (2001) ("[T]he health risks to mother and child inherent in [cloning] . . demand that it be banned.").

14 NAT'L RESEARCH COUNCIL, SCIENTIFIC AND MEDICAL ASPECTS OF HUMAN REPRODUCTIVE CLONING 1 (2002).

Human reproductive cloning ... is dangerous and likely to fail. The panel therefore unanimously supports the proposal that there should be a legally enforceable ban on the practice of human reproductive cloning. . . . The scientific and medical considerations related to this ban should be reviewed within 5 years. The ban should be reconsidered only if at least two conditions are met: ( 1 ) a new scientific and medical review indicates that the procedures are likely to be safe and effective and (2) a broad national dialogue on the societal, religious, and ethical issues suggests that a reconsideration of the ban is warranted.

Id. at ES-1 to ES-2. See also NAT'L RESEARCH COUNCIL, StEM CElls and the FutURE OF REGENERATIVE MEDICINE (2001). 
to predict the future without overwhelming data to support them, many believe that human cloning or inheritable genetic alternations at the embryo level will never be safe because they will always be inherently unpredictable in their effects on the children and their offspring. As Stewart Newman has noted, for example, it is unlikely that a human created from the union of "two damaged cells" (an enucleated egg and a nucleus removed from a somatic cell) could ever be healthy. 15 of course, adding genetic modification to the somatic cell's nucleus just adds another series of events that could go wrong, because genes seldom have a single furction, but will usually interact in complex and unpredictable ways with other genes. 16 It is worth underlining that the dangers are not just physical, but also psychological. Whether cloned children could ever overcome the psychological problems associated with their origins is unknown and perhaps unknowable.17 In short, the safety issues, which inherently make attempts to clone or genetically alter a human being unethical human experiments, provide sufficient scientific justification for the treaty alone.

If and when safety can be assured, assuming this will ever be possible, two primary arguments have been set forth in favor of proceeding with cloning (and its first cousin, inheritable genetic alterations). First, cloning is a type of human reproduction that can help infertile couples have genetically-related children. Second, cloning is a part of human "progress" that could lead to a new type of genetic immortality, therefore, to prevent it is to be anti-scientific.

The infertility argument is made by physiologist Panos Zavos and his former Italian colleague, infertility specialist Severino Antinori. They argue that the inability of a sterile male to have a genetically-related child is such a human tragedy that it justifies human cloning. ${ }^{18}$ This view not only ignores the rights and interests

is Stuart A. Newman, Speech at the "Beyond Cloning" Conference, Boston University (Sept. $21,2001)$.

16 See, e.g., Jon W. Gordon, Genetic Enhancement in Humans, 283 SCIENCE 2023, 2023

17 Hans Jonas, for example, argued that it is a crime against the clone by depriving the cloned child of his or her "existential right to certain subjective terms of [ ] being." HANS JONAS, Philosophical ESSAYS: From ANCIENT CREED to TEChNological MAN 160 (1974). Jonas believes that a clone will not have a "right to ignorance" or the "right . . to a unique genotype." Id. Instead, a clone knows:

[A]ltogether too much about himself and is known ... altogether too well by others. Both facts are paralyzing for the spontaneity of becoming himself .... [T] antecedently robbed of the freedom which only under the protection of ignorance can thrive: and to rob a human-to-be of that freedom deliberately is an inexplicable crime that must not be committed even once.

Id. at 161 . Human reproductive cloning poses both physical and psychological risks to children who might be conceived using this technique. In animals, cloning currently only results in a successful pregnancy three to five percent of the time. And, even in those rare instances, many of the resulting offspring suffer-one-third die shortly before or right after birth. Other cloned animals seem perfectly healthy at first and then suffer heart and blood vessel problems, underdeveloped lungs, diabetes, immune system deficiencies and severe growth abnormalities. The mothers who gestate clones are also at risk, due to the often abnormally large size of the offspring produced-some cattle clones for example, are born up to twice the normal weight expected for calves.

18 Tim Adams, Interview: The Clone Arranger, THE OBSER VER, Dec. 2, 2001, at 3 (comments of Severino Antinori).

Male infertility grows .... My invention of ICSI has helped. I have helped men whose sperm are misformed or too slow. I have helped men whose sperm does not come out from their testes! And the next step [cloning] is to help men who-traumatico!-have lost their ability to produce any sperm at all. Through war or accident or cancer. I will help only stable, loving couples. Some doctors say this is a step too far, but those same doctors have said that about all the other steps too. Very few doctors are pioneers! Very few have both the knowledge and the, the, the ... courage.

Id. See also ROBERT WINSTON, The Promise of Cloning for Human Medicine, 314 BRIT. MED. J. 913 
of women and children (even if only males are to be cloned, eggs must be procured from a woman, the embryos must be gestated by a woman and the child is the subject of the experiment), but also contains a highly-contested assertion: that asexual genetic replication or duplication should be seen as "human reproduction." 19 In fact, humans are a sexually reproducing species and have never reproduced or replicated themselves asexually.

Asexual replication may or may not be categorized by future courts as a form of human reproduction, but there are strong arguments against it. First, asexual reproduction changes a fundamental characteristic of what it means to be human (i.e., a sexually reproducing species) by making sexual reproduction involving the genetic mixture of male and female gametes optional. Second, the "child" of an asexual replication is also the twin brother of the male "parent," a relationship that has never existed before in human society. The first clone, for example, will be the first human being with a single genetic "parent" (unless the biological grandparents are taken to be the actual "parents" of the clone). ${ }^{20}$ Third, the genetic replica of a genetically sterile man would be sterile himself and could only "reproduce" by cloning. This

(1997) (advocating for the use of cloning to help infertile men have genetically-related children). Zavos and Antinori dissolved their partnership in 2002. David Brown, Human Clone's Birth Predicted, WASH. POST, May 16, 2002, at A8.

19 See generally, Michael H. Shapiro, I Want a Girl (Boy) Just Like the Girl (Boy) that Married Dear Old Dad (Mom): Cloning Lives, 9 S. CAL. INTERDISC. L.J. I (arguing, in part, that cloning should be considered reproduction, for the essence of reproduction is the creation of a new person).

A variety of personal desires may interest people in creating a child through cloning or germline genetic engineering. The NBAC report suggests it would be "understandable, or even, as some have argued, desirable" to create a cloned child from one adult if both members of the couple have a lethal recessive gene; from a dying infant if his father is dead and the mother wants an offspring from her late husband; or from a terminally ill child to create a bone marrow donor. CLONING HUMAN BEINGS, supra note 12, at 78-80. Some of the experts testifying before the NBAC suggested that cloning should be appropriate in exceptional circumstances. Rabbi Elliot Dorff opined that it would be "legitimate from a moral and a Jewish point of view" to clone a second child to act as a bone marrow donor so long as the "parents" raise that second child as they would any other. Id. at 55. Rabbi Moshe Tendler raised the scenario of a person who was the last in his genetic line and whose family was wiped out in the Holocaust. "l would certainly clone him," said Tendler. Id. For other Jewish perspectives supporting cloning, see Peter Hirschberg, Be Fruitful and Multiply and Multiply and Multiply, JERUSALEM REP., Apr. 16, 1998, at 33. In contrast, the Catholic viewpoint is that cloning "is entirely unsuitable for human procreation even for exceptional circumstances." ClONING HUMAN BEINGS, supra note 12, at 55 .

20 Before a U.S. Senate Committee, which also heard from lan Wilmut shortly after he had announced the birth of Dolly, one of us made the argument that a human clone would be the first human being with one genetic parent. Testimony on Scientific Discoveries and Cloning: Challenges for Public Policy. Before the Sen. Subcomm. on Public Health and Safety. Sen. Comm. on Labor and Human Resources, 105th Cong. 25 (1997) (statement of George J. Annas), available at http://www.bumc.bu.edu/www/sph/lw/pvl/Clonetest.htm. Population geneticist Richard Lewontin challenged this assertion, writing:

A child by cloning has a full set of chromosomes like anyone else, half of which were derived from a mother and half from a father. It happens that these chromosomes were passed through another individual, the cloning donor, on the way to the child. The donor is certainly not the child's "parent" in any biological sense, but simply an earlier offspring of the original parents.

R.C. Lewontin, Confusion over Cloning, N.Y. REV. Books, Oct. 23, 1997, at 20.

It should be noted that Lewontin's position takes genetic reductionism to its extreme: people become no more than containers of their parent's genes, and their parents have the "right" to treat them not as individual human beings, but rather like embryos-entities that they can "split" or "replicate" without consideration of the child's choice or welfare. Children, even adult children, under this view have no say as to whether or not they are replicated because it is their "parents," not them, who are "reproducing." This radical redefinition of reproduction and the denial to children of the choice to procreate or not turns out to be an even stronger argument against cloning children than its biological novelty. George J. ANNAS, SOME ChOICE: LAW, MEDICINE \& THE MARKET 13 (1998). 
means either that infertility is not a major problem (because if it were, it would be unethical for a physician to intentionally create a child with this problem), or that the desire of existing adults should take precedent over the welfare of children. We find neither conclusion persuasive, and this is probably why, a.:hough some ethicists believe that cloning could be considered a form of human reproduction, infertility specialists have not joined Antinori's call for human cloning as a treatment for infertile males. In fact the organization that represents infertility specialists in the United States, and is generally opposed to the regulation of the infertility industry, the American Society of Reproductive Medicine, has nonetheless consistently opposed human cloning. ${ }^{21}$

There are, nonetheless, legal commentators who believe that human cloning should be classified as a form of human reproduction, and protected as such, at least if it is the only way for an individual to have a "genetically-related child." The strongest proponent of this view is probably John Robertson, 22 although Ronald Dworkin ${ }^{23}$ shares his enthusiasm as well. Suffice it to say here that it is very unclear that human reproduction or procreation of a kind protected by principles of autonomy and self-fulfillment can be found in a "right to have a genetically-related child." It cannot be just the genetic tie that is important in human reproduction, because if it were, this could be accomplished by having one's twin brother have a child with one's wife 24-the genetic tie would be identical, yet few, if any, would argue that this method of reproduction should satisfy the twin's right to have a "genetically-related child." Genes are important, but there is more to human reproduction, as protected by the U.S. Constitution, than simple genetic replication.

The second major argument in favor of human cloning is that it can lead to a form of immortality. This is the premise of the Raelian cult that has chartered its own corporation, Clonaid, to engage in human cloning. The leader of the cult, who calls himself Rael (formerly Claude Vorilhon, the editor of a French motor sport magazine), believes that all humans were created in the laboratories of the planet Elohim and that the Elohims have instructed Rael and his followers to develop cloning on Earth to provide earthlings with a form of immortality. ${ }^{25}$ The Raelians, of course, can believe whatever they want to; but just as human sacrifice is illegal, experiments that pose a significant danger to women and children can also be outlawed, 26 and the religious beliefs of this cult do not provide a sufficient justification to refrain from outlawing cloning.

Just as two primary arguments in favor of cloning and inheritable genetic alterations have emerged over the past five years, so have two basic arguments about the future regulation of these technologies. The first, exemplified by Lee Silver, is that these technologies, while not necessarily desirable, are unstoppable because the market combined with parental desire will drive scientists and physicians to offer these services to demanding couples.27 Similar to the way parents now seek early educational enrichment for their children, he believes that parents of the future will

21 See, e.g., ETHICS COMM., AM. SOC'Y REPRODUCTIVE MED., Human Somatic Cell Nuclear Transfer (Cloning), 74 FERTILITY \& STERLLITY 873, 873-76 (2000).

22 John A. Robertson, Two Models of Humon Cloning, 27 HofSTRA L. REV. 609 (1999).

23 Ronald DWorkin, Sovereign VIRTUe: The Theory and Practice OF EQUality 437-42

(1997).

24 Leon Kass made this point in anothet context. LEON R. KASS, TOWARD A MORE NATURAL SCIENCE: BIOLOGY AND HUMAN AFFAIRS 110-111 (1985).

25 See RAEL, THE TRUe Face Of GOd (Int'l Raelian Movement 1998).

26 See Jay Katz, EXPERIMENTATION With Human Benngs (Russell Sage Found. 1972).

27 LEE SILVER, REMAKING EdEN: CLONING AND BEYOND IN A BRAVE NEW WORLD 123 (1997). 
seek early genetic enhancement to give them a competitive advantage in life. Silver thinks this will ultimately lead to the creation of two separate species or subspecies, the GenRich and "the naturals." 28

A related "do nothing" argument is that regulation may not be needed because the technologies will not be widely used. The thought is that humans may muddle through, either because the science of human genetic alterations may never prove possible, or because it will be used by only a handful of humans because most will instinctively reject it. Colin Tudge, a proponent of this argument, also accepts Silver's argument that the market is powerful and often determinative, but nonetheless believes that the three fundamental principles of all religions-personal humility, respect for fellow humans and reverence for the universe as a whole-could lead the vast majority of humans to reject cloning and genetic alterations. ${ }^{29}$ In his words:

The new technologies, taken to extremes, threaten the idea of humanity. We now need to ask as a matter of urgency who we really are and what we really value about ourselves. It could all be changed after all-we ourselves could be changed-perhaps simply by commercial forces that we have allowed to drift beyond our control. If that is not serious, it is hard to see what is. ${ }^{30}$

We agree with Tudge that the issues are serious. We think that they are too serious to be left to religions or human instinct, or even to individual national legislation, to address.

In this regard, we find a second approach, that of a democratically-formed regulatory scheme more reasonable. Indeed, in our view the widespread condemnation of human replicative cloning by governments around the world means that cloning provides a unique opportunity for the world to begin to work together to take some control over the biotechnology that threatens our very existence. ${ }^{31}$

The primary arguments against cloning and inheritable genetic alterations, which we believe make an international treaty the appropriate action, have been summarized in detail elsewhere. In general, the arguments are that these interventions would require massive dangerous and unethical human experimentation, ${ }^{32}$ that cloning would inevitably be bad for the resulting children by restricting their right to an "open future," 33 that cloning would lead to a new eugenics movement for "designer children" (because if an individual could select the entire genome of their future child, it would seem impossible to prohibit individuals from choosing one or more specific genetic characteristics of their future children), ${ }^{34}$ and that it would likely lead to the creation of a new species or subspecies of humans,

28 Id. at 4.

29 Colin Tudge, The Impact of the Gene: From Mendel's Peas to Designer Babies 4 (2000).

30 Id. at 342. See also lan Wilmut ET. AL., THE SECOND CREation: Dolly and the Age of BIOLOGICAL CONTROL 267-98 (2000) (discussing the implications of cloning for humankind).

31 See the appendix to this Article for current national laws on human cloning and inheritable modifications.

32 See generally The NAZI Doctors AND THE NUREMberg CODE 3 (George J. Annas \& Michael A. Grodin eds., 1992) (exploring the "history, context, and implications of the Doctor's Trial at Nuremberg and the impact of the Nuremberg Code on subsequent codes of research ethics and international human rights").

33 JONAS, supra note 17, at 161-62.

34 It is in this sense that children become "manufactured" products. See KaSS, supra note 24, at $71-73$. 
sometimes called the "posthuman." 35 In the context of the species, the last argument has gotten the least attention, and so it is worth exploring.

Specifically, the argument is that cloning will inevitably lead to attempts to modify the somatic cell nucleus not to create genetic duplicates of existing people, but "better" children.36 If this attempt fails, that is the end of it. If it succeeds, however, something like the scenario envisioned by Silver and others such as Nancy Kress, ${ }^{37}$ will unfold: a new species or subspecies of humans will emerge. The new species, or "posthuman," will likely view the old "normal" humans as inferior, even savages, and fit for slavery or slaughter. The normals, on the other hand, may see the posthumans as a threat and if they can, may engage in a preemptive strike by killing the posthumans before they themselves are killed or enslaved by them. It is ultimately this predictable potential for genocide that makes species-altering experiments potential weapons of mass destruction, and makes the unaccountable genetic engineer a potential bioterrorist. It is also why cloning and genetic modification is of species-wide concern and why an international treaty to address it is appropriate. ${ }^{38}$ Such a treaty is necessary because existing laws on cloning and inheritable genetic alterations, although often well-intentioned, have serious limitations.

\section{INTERNATIONAL RESTRICTIONS ON CLONING AND GENETIC MODIFICATIONS}

Despite the fact that no children have been born as a result of these speciesaltering interventions, policymakers around the world have expressed concerns about the use of these technologies. Some countries' lawmakers have enacted bans on these proposed experimental technologies, while others have assumed that existing laws apply to the techniques. However, both categories of laws have shortcomings.

\section{A. MORATORIA}

Some countries have approached species-altering procedures with caution, instituting moratoria in order to consider the vide range of impacts of the technologies. Israel, for example, has stated that the purpose of such moratoria is to have time "to examine the moral, legal, social and scientific aspects of such types of

35 See Annas, supra note 6, at 776-780; Fukuyama, supra note 7, at 22; Francis Fukuyama, Natural Rights and Human History, NAT'L INTEREST, Summer 2001, at 19, 30. For arguments favoring inheritable genetic modifications, see, for example, ENGINEERING THE HUMAN GERMLNE (Gregory Stock \& John Campbell eds., 2000); GREGORY STOCK, REDESIGNING HUMANS (2002) (arguing, among other things, that it is inherent in our human nature to want to change our human nature, and that an international treaty would be unenforceable because every nation would have an economic incentive to defect and capture the market for inheritable modifications)

36 See. e.g., WILMUT ET AL., supra note 30, at 5-6 (discussing how the post-Dolly experiments were designed to use cloning techniques to make "better animals," which was aluays lan Wilmut's and Keith Campbell's plan for cloning technology). See also Angelika E. Shnieke et al., Human Factor $I X$ Trans-genic Sheep Produced by Transfer of Nuclei from Transplanted Fetal Fibroblasts, 278 SCIENCE 2130 (1997).

37 See, for example, Nancy Kress's Beggars series: BEGGars IN SPAlN (1993); BEGGarS AND CHOOSERS (1994); and BEGGAR'S RIDE (1996).

38 See Annas, supra note 6, at 778-81. An alternative scenario, that sees equal access to genetic "improvement" by all seems like pie in the sky to us in a world where fewer than ten percent of the population has access to contemporary medical care, and even in the world's richest country, more than forty million people lack health insurance. We do not think it is reasonable to even discuss equal access to genetic alterations until all members of the species have access to current medical technologies as a matter of right. 
intervention and their implication on human dignity." 39 In 1998, Israel adopted a five-year moratorium on cloning a human being, defining cloning as "the creation of an entire human being, who is genetically identical to another person or fetus, alive or dead." 40 The same law banned interventions to create a child through the use of reproductive cells that have undergone a permanent intentional genetic modification. ${ }^{41}$ Some countries are using that same time period to consider the wealth of issues involved in species-altering procedures. ${ }^{42}$ Others, though, have already determined that such technologies are inimical to human values and human dignity. ${ }^{43}$

\section{B. Limitations in Human Cloning Bans}

Some countries have attempted to ban human cloning, but have used language that inadvertently creates ambiguities. In other countries, policymakers may believe that their laws ban human cloning, but that may not be the case. Japan, for example, explicitly and clearly bans cloning. ${ }^{44}$ Germany bans attempts to bring to birth a human embryo having the same genetic information as another embryo.45 Spain, Victoria, Australia and Western Australia prohibit cloning and other procedures that bring about the birth of an identical human being. ${ }^{46}$ But because cloning includes mitochondrial DNA from the woman whose egg is used, the clone will not have a completely identical genome (unless a woman clones herself and uses her own egg) and thus the practice of cloning may not be adequately banned.

Some countries ban embryo research, ${ }^{47}$ but cloning through the Dolly technique of somatic cell nucleus transfer (SCNT) may not be viewed as embryo research. The SCNT technique utilizes an experimental procedure involving an egg to create an embryo. 48 Once the embryo has been created, no experimental technique is necessary. The resulting embryo can be implanted into a woman using the same standard clinical technique as is used in the in vitro fertilization (IVF) process.

British lawmakers thought they had a ban in place to prevent human cloning. The British have created a regulatory structure for IVF and related technology under the Human Fertilisation and Embryology Act of 1990 (HFEA). ${ }^{49}$ The statute requires

39 Prohibition of Genetic Intervention Law No. 5759 (1998)

40 Id. $\$ 3(1)$.

41 Id. $\S 3(2)$.

42 See Ania Lichtarowicz, Scientist Warns on Human Cloning, BBC NEwS, at http://news.bbc. co.uk/hi/English/ world/Europe/newsid_1719000/1719195.stm (Dec. 21, 2001) (noting that Spain and Belgium are still considering different types of legislation for adoption).

43 Britain to Ban Human Cloning, CNN.COM, at http:/www.cnn.com/2001/WORLD/curope/ UK/04/19/cloning. legislation/index.html (Apr. 19, 2001). See also Human Reproductive Cloning Act 2001, U.K. Stat. 2001, ch. 23, Enactment Clause (Eng.). (stating that the law "prohibit[s] the placing in a woman of a human embryo which has been created otherwise than by fertilisation").

44 Ministry Bans Cloning Technology for Humans, DAILY YOMIUR1, July 29, 1998, at 2.

45 Gesetz zum Schutz von Embryonen (Embryonenschutzgesetz), v.13.12.1990 (BGBI. I S.2747). [Federal Embryo Protection Law].

46 Manipulacion Gentica y Reproduccion [Genctic Manipulation and Reproduction]; Victoria Infertility Treatment Act, 2000; Human Reproductive Technology Act, 1991, § 7(1)(d)(i) (W. Austl.).

47 See, e.g., The Logical Next Step? An International Perspective on the Issues of Human Cloning and Generic Technology, 4 ILSA J. INT'L \& COMP.L. 697, 721 -25 (1998).

48 See. e.g., Valerie S. Rup, Human Somatic Cell Nuclear Transfer Cloning, the Race to Regulate, and the Constitutionality of the Proposed Regulations, 76 U. DET. MERCY L. REV. 1135 , 1138 -39 (1999); Christine Willgoos, Note, FDA Regulation: An Answer to the Questions of Human Cloning and Germline Gene Therapy, 27 AM. J.L. \& MED. 101, 103 (2001).

49 Human Fertilisation and Embryology Act, 1990, ch. 37, Enactment Clause (Eng.). See generally Ruth Deech. The legal Regulation of Infertility Treatment in Britain, in CROSSCURRENTS: 
that activities falling within the act, such as the creation, storage, handling and use of human embryos outside of the body, must only be undertaken in licensed facilities. ${ }^{50}$ Only activities enumerated in the Act, or approved by the Human Fertilisation and Embryology Authority, may be undertaken.5i Certain activities, such as placing a human embryo in an animal, are completely prohibited. The British Act defines an "embryo" as a "live human embryo where fertilisation is complete" or "an egg in the process of fertilisation." 52 British lawmakers assumed human reproductive cloning was prohibited under the Act because it was not listed as an allowable activity with human embryos. ${ }^{53}$

In November 2000, the Pro-Life Alliance brought suit claiming that embryos created through cloning are not covered by HFEA. On November 15, 2001, the British High Court of Justice, Queen's Bench Division, Administrative Court, ruled in favor of the Pro-Life Alliance. The judge said, "With some reluctance, since it would leave organisms produced by CNR [cell nuclear replacement] outside the statutory and licensing framework, I have come to the conclusion that to insert these words would involve an impermissible rewriting and extension of the definition." 54 In response, Parliament passed new legislation just two weeks after the ruling making it an offense, punishable by up to ten years in prison, for a person to place "in a woman a human embryo which has been created otherwise than by fertilisation." 55 Ultimately, a higher court ruled that a human embryo created by cloning was in fact covered by HFEA. 56

\section{BANS ON INHERITABLE GENETIC INTERVENTIONS}

Internationally, the bans on inheritable or germline genetic interventions are general enough to reach a wide range of technologies. These laws reflect a profound understanding of the need to avoid the social pressures to engineer a "better" race, as occurred in the Nazi era. German law understandably forbids germline intervention. ${ }^{57}$ Victoria, Australia, in its Infertility Treatment Act of 1995, has comprehensive language prohibiting germline genetic alterations. 58 The law prohibits altering the genetic constitution of gametes ${ }^{59}$ or altering the genetic, pronuclear or nuclear constitution of a zygote. $60 \mathrm{~A}$ Western Australia law prohibits the alteration of the genetic structure of an egg in the process of fertilization or an embryo. ${ }^{61}$ In Norway, a 1994 law provides that the "human genome may only be altered by means of somatic gene therapy for the purpose of treating serious disease

Family LAW aNd Policy in the U.S. ANd ENGLANd $165-86$ (Sanford Katz et al., eds, 2000).

50 Human Fertilisation and Embryology Act. ch. 27, §§ 3, 12.

51 Id. ch. 37, $\$ 41$.

52 Id. ch. 37, Enactment Clause.

53 The Act also had a ban, predating Dolly, on the replacement of the nucleus of a human embryo cell with that of any person or embryo, but that prohibition does not cover somatic cell nucleus transfer into a human egg.

54 Pro-Life Alliance v. Sec'y State for Health, CO/4095/2000 (Q.B. 2001), available at 2001 WL 1347031 .

55 Human Reproductive Cloning Act, 2001, U.K. Stat. 2001 ch. $23 \S 1$.

S6 $R$ (Quintavalle) v. Sec'y of State for Health, 2 WLR 550 (C.A. 2002), reprinted at Cell Nuclear Replacement Organism is "Embryo," THE TIMES (London), Jan. 25, 2002.

57 Federal Embryo Protection Law, 1990 (Eng.)

58 Victoria Infertility Treatment Act, 1995.

59 Federal Embryo Protection Law, 1990 (Eng.), at Part 5, $\$ 39(1)$.

60 Federal Embryo Protection Law, 1990 (Eng.), at Part 5. § 39(2).

61 Human Reproductive Technology, 1991, $\$ 7(1)(j)$ (Austl.). 
or preventing serious disease from occurring."62 Sweden prohibits research that attempts to modify the embryo. ${ }^{63}$ France, too, prohibits such interventions. ${ }^{64}$ Costa Rica bans any manipulation or alternation of an embryo's genetic code. ${ }^{65}$

\section{THE LEGAL STATUS OF HUMAN CLONING AND GERMLINE GENETIC INTERVENTION IN THE UNITED STATES}

In 1997 President Clinton issued an executive order banning the use of federal funds for human cloning. ${ }^{66}$ However, such a ban has little effect on private fertility clinics. For twenty years, the federal government has refused to provide funds for research on IVF, but that has not stopped the hundreds of privately-financed IVF clinics from creating tens of thousands of babies. The ban on federal funding of embryo research and human cloning does not, of course, apply to scientists who wish to undertake either activity with private funds.

\section{A. THE APPLICATION OF U.S. LAWS BANNING EMBRYo RESEARCH TO HUMAN CLONING AND INHERTABLE GENETIC INTERVENTION}

Existing American laws banning embryo research, dating back in some states to the mid-1970s, could potentially be used to prohibit certain species-altering technologies at the experimental stage.67 Eleven states have laws regulating research and/or experimentation on conceptuses, embryos, fetuses or unborn children that use broad enough language to apply to early embryos. ${ }^{68}$ It should be noted, however, that these bans would not apply once the techniques are no longer considered to be research and instead are thought of as standard practice.

Several arguments could be made to suggest that most of the embryo research statutes should be construed narrowly so as not to apply to cloning. Eight of the eleven states prohibit some form of research on some product of conception, referred

62 The Act Relating to the Application of Biotechnology in Medicine, ch. 7.

63 Law No. 115 of March 14, 1991, Act Concerning Measures for the Purposes of Research or Treatment in Connection with Fertilized Human Oocytes (1993).

64 Law No. 94.654 of July 29, 1994, on the Donation and Use of Elements and Products of the Human Body, Medically Assisted Procreation, and Prenatal Diagnosis.

65 Decree No. 24029-S: A Regulation on Assisted Reproduction, Feb. 3, 1995.

66 See Memorandum on the Prohibition on Federal Funding for Cloning of Human Beings, 33 WEEKLY COMP. PRES. DOC. 281 (Mar. 4, 1997); see also Transcript of Clinton Remarks on Cloning, U.S. NEWSWIRE, Mar. 4, 1997, available at 1997 WL 5711155.

67 Yet despite the risks, only six states-California, Iowa, Louisiana, Michigan, Rhode Island and Virginia-have passed legislation that prohibits human reproductive cloning. CAL. HEALTH \& SAFETY CODE ANN. \$24185 (West 2002); IOWA CODE § 707B, CSB 218 (S.F. 2118) (2002); LA. REV. STAT. 40:1299.36.2 (West 2002); MICH. COMP. LAWS ANN. \$ 750.430a (West 2001); R.I. GEN. LAWS $\S 23-16.4$ (2001); VA. CODE ANN. $\$ \S 32.1-162.21,162.22$ (Michic 2002). In addition, Missouri prohibits the use of any state funds to bring about the birth of a child via cloning techniques. MO. ANN. STAT. $\S 1.217$ (West 2002). The U.S. House of Representatives in July 2001 voted to ban human cloning. See The Human Cloning Prohibition Act of 2001, H.R. 2505, 107th Cong. (2001). See also Sheryl Gay Stolberg, House Backs Ban on Muman Cloning for any Objective, N.Y. TIMES, Aug. 1, 2001 , at Al. At the time of this writing, the U.S. Senate was scheduled to consider this issue in 2002.

68 FLA. STAT. ANN. $\$ 390.0111(6)$ (West 2002); LA. REV. STAT. ANN. $\$ 9: 121-129$ (West 2002); ME. Rev. Stat. ANN. tit. 22, $\$ 1593$ (2002); MASS. Gen. LAwS ANN. ch. 112, $\$ 12$ J West (2002); MICH. COMP. LAWS ANN. $\$ 333.2685-2692$ (West 2002); MINN. STAT. $\$ 145.421$ (2001); N.D. CENT. CODE § 14-02.2-01 (2001); N.H. REV. STAT. ANN. \$ 168-B:1S (2002); 18 PA. CONS. STAT. $§$ 3216 (2001); R.I. GEN. LAwS $\$ 11-54-1$ (2001). A South Dakota law bans research that destroys an embryo, when such research has not been undertaken to preserve the life and health of the particular embryo. S.D. CODIFIED LAWS $\$$ 34-14-18 (Michie 2001). 
to in the statutes as a conceptus, ${ }^{69}$ embryo, ${ }^{70}$ fetus ${ }^{71}$ or unborn child. ${ }^{72}$ With cloning, an argument could be made that the experimentation is being done on an egg, not the product of conception, and thus these statutes should not apply. ${ }^{73}$ By the time the egg is re-nucleated, the experiment or research has already been completed and the resulting embryo could be implanted under standard practices, as with IVF.

Moreover, two of the eleven states define the object of protection-the conceptus (Minnesota) or unborn child (Pennsylvania)-as the product of fertilization. If transfer of nucleic material is not considered fertilization (as was the case in the initial court decision in England), then these laws would not apply. In addition, at least eight of the states banning embryo research are sufficiently general that they might be struck down as unconstitutionally vague. ${ }^{74}$

Under New Hampshire's embryo research law, a researched-upon pre-embryo may not be transferred to a uterine cavity. ${ }^{75}$ Thus, if a re-nucleated oocyte is considered to be a pre-embryo and if cloning is considered to be research, it would be impermissible in New Hampshire to implant the resulting conceptus to create a child. Possibly as a result of the deficiencies in the embryo-research laws, three of the states with embryo research bans have new laws banning cloning. ${ }^{76}$

The embryo research bans could potentially affect the practice of inheritable genetic alterations. Under these laws, research attempts to insert genes into embryos would be prohibited if undertaken strictly to gain scientific knowledge. If the genes were added in an attempt to "cure" a particular embryo that was destined to go to term, however, it is likely to be permissible in most states. Maine might still ban it, because it prohibits "any form of experimentation." embryo research bans explicitly allow procedures for the purpose of providing a health benefit to the fetus or embryo, and therefore might not affect gene alterations. $^{78}$ In some states, the embryo research bans might forbid the use of evolving or insufficiently-tested therapies if such therapies were not necessary to the preservation of the life of the fetus. However, these laws or related laws generally require the protection and preservation of viable fetuses. Therefore, it seems unlikely that the embryc research laws in these states would be invoked to enforce the

69 MINN. STAT. ANN. \$145.421.

70 MICH. COMP. LAWS ANN. $\$ 333.2685$.

71 FLA. STAT. ANN. $\$ 390.0111(6)$; ME. REV. STAT. ANN. tit. 22, $\$ 1593$; MASS. GEN. LAWS ANN. ch. 112, § 12J; MICH. COMP. LAWS ANN. \$333.2685-.2692; N.D. CENT. CODE § 14-02.2-0I; R.I. GEN. LAWS $\S 11-54-1$.

7218 PA. CONS. STAT. $\$ 3216$.

73 See Ronald M. Green, The Ethical Considerations, 286 SCIENTIFIC AM. 1850,4850 (Jan. 2002) (arguing that when Advanced Cell Technology created what the company called the "world's first human cloned embryo," all it had really done was create an "activated egg"). The company's president, Michael West, had previously argued that the company's work did not violate the Massachusetts Federal Research statute, and we believe he is correct in this argument.

74 Four states' fetal research bans-those of Arizona, Illinois, Louisiana, and Utah-have already been struck down on those grounds. Forbes v. Napolitano, 236 F.3d 1009 (9th Cir. 2000); Margaret S. v. Edwards, 794 F.2d 994, $998-99$ (5th Cir. 1996); Jane L. v. Bangerter, 61 F.3d 1493, 1499-1502 (10th Cir. 1995); Lifchez v. Hartigan, 735 F. Supp. 1361, 1363-66 (N.D. III. 1990).

75 N.H. REV. STAT. ANN. $\$ 168-B: 15$ (II) (2002).

76 LA. REV. STAT. ANN. \$40:1299.36.2 (West 2002); MICH. COMP. LAWS ANN. $\S 333.16275$, 750.430(a) (West 2001); R.I. GEN. LAWS $§ 23-16.4-2$ (2001).

77 ME. REV. STAT. ANN. tit. 22, §1593 (2002).

78 See, e.g., FLA. STAT. ANN. \$ $390.0111(6)$ (West 2002); MASS. GEN. iAWS ANN. ch. 112, § $12 \mathrm{~J}$ (West 2002); MICH. COMP. LAWS ANN. $\$ 333.2685-.2692$ (West 2002); MINN. STAT. $§ 145.421$ (2001); N.D. CENT. CODE $\S 14-02.2-01$ (2001); 18 PA. CONS. STAT. $\S 3216$ (2001); R.I. GEN. LAWS $\S$ $11-54-1$ 
withbolding of gene therapy as a form of treatment if doctors argued that the procedure held out some actual promise of a health benefit to the embryo and prospective child.

The New Hampshire and Louisiana laws have unique twists. New Hampshire's law might ban creating a child with inheritable alterations because it prohibits the transfer of any embryo donated for research to a uterus. ${ }^{79}$ Louisiana's law has the opposite effect, prohibiting farming or culturing embryos solely for research purposes, ${ }^{80}$ but apparently allowing research as long as the embryo is implanted.

\section{B. NATIONAL IMPLICATIONS OF BANNING CLONING AND INHERITABLE ALTERATIONS}

We do not believe there is any constitutional prohibition that would limit the legal authority of the federal government to enter into an international treaty banning human cloning and inheritable genetic alterations, although this question has been the subject of wide discussion in the legal literature. ${ }^{81}$

79 N.H. REV. STAT. ANN. \$ 168-B:15(II).

80 LA. REV. STAT. ANN. $\$ 9: 122$ (West 2002).

81 The right to make decisions about whether or not to bear children is constitutionally protected under the constitutional right to privacy. See, e.g., Eisenstadt v. Baird, 405 U.S. 438 (1972); Griswold v. Connecticut, 381 U.S. 479 (1965). The constitutional right to liberty also affords such protection. See Planned Parenthood of S.E. Pa. v. Casey, 505 U.S. 833, 857 (1992). The U.S. Supreme Court in 1992 reaffirmed the "recognized protection accorded to liberty relating to intimate relationships, the family, and decisions about whether to bear and beget a child." Id. at 857 . Early decisions held that the right to privacy protected married couples' ability to make procreative decisions, but later decisions focused on individuals' rights as well. The U.S. Supreme Court has stated, "If the right of privacy means anything, it is the right of the individual, married or single, to be free from unwarranted govermmental intrusion into matters so fundamentally affecting a person as the decision whether to bear or beget a child." Eisenstadt, 405 U.S. at 453.

A federal district court has indicated that the right to make procreative decisions encompasses the right of an infertile couple to undergo medically-assisted reproduction, including IVF and the use of a donated embryo. Lifchez v. Hartigan, 735 F. Supp. 1361, 1367-69. (N.N. Ill. 1990). Lifchez held that a ban on research on conceptuses was unconstitutional because it impermissibly infringed upon a woman's fundamental right to privacy. Id. at 1363 . Although the lllinois statute banning embryo and fetal research at issue in the case permitted IVF, it did not allow embryo donation, embryo freezing or experimental prenatal diagnostic procedures. Id. at 1365-70. The court stated, "It takes no great leap of logic to see that within the cluster of constitutionally protected choices that includes the right to have access to contraceptives, there must be included within that cluster the right to submit to a medical procedure that may bring about, rather than prevent, pregnancy." $/ d$. at 1377 . The court also held that the statute was impermissibly vague because of its failure to define "experiment" or "therapeutic." Id. at 1376.

Some commentators argue that the Constitution similarly protects the right to create a child through cloning. See John Robertson, Views on Cloning: Possible Benefits, Address Before the National Bioethics Advisory Commission (Mar. 14, 1997), available at http:/bioethics.georgetown.edu /nbac/transcripts/index.html. This seems to be a reversal of Robertson's earlier position that cloning "Inay deviate too far from prevailing conception of what is valuable about reproduction to count as a protected reproductive experience. At some point attempts to control the entire genome of a new person pass beyond the central experiences of identity and meaning that make reproduction a valued experience." JOHN ROBERTSON, CHILDREN OF CHOICE: FREEDOM AND THE NEW REPRODUCTIVE TECHNOLOGIES 169 (1994).

However, cloning is sufficiently different from normal reproduction and the types of assisted reproduction protected by the Lifchez case that cons:itutional protections should not apply. In even the most high-lech reproductive technologies available, a mix of genes occurs to create an individual with a genotype that has never before existed. In the case of twins, two such individuals ale created. Their futures are open and the distinction between themselves and their parents is acknowledged. In the case of cloning, however, the genotype already exists. Even though it is clear that the individual will develop into a person with different traits because of different social, environmental and generational influences, there is evidence that the fact that he or she posses an existing genotype will affect how the 
The United States itself currently has no federal law on either cloning or inheritable genetic modification, even though both President George W. Bush and former President Bill Clinton are in favor of outlawing human "reproductive" cloning. ${ }^{82}$ In August 2001 , the House of Representatives voted to outlaw both

resulting clone is treated by himself, his family and social institutions.

In that sense, cloning is sufficiently distinct from traditional reproduction or altemative reproduction to not be considered constitutionally protected. It is not a process of genetic mix, but of genetic duplication. It is not reproduction, but a sort of recycling, where a single individual's genome is made into someone else. This change in kind in the fundamental way in which humans can "repreduce" represents such a challenge to human dignity and the potential devaluation of human life (even comparing the "original" to the "copy" in terms of which is to be more valued) that even the search for an analogy has come up empty handed. Testimony on Scientific Discoveries and Cloning: Challenges for Public Pclicy, Before the Sen. Subcomm. on Public Health and Safety. Sen. Comm. on Labor and Human Resources, 105th Cong. 25 (1997) (statement of George J. Annas), available at http://www.bumc.bu.cdu/www/sph/lw/pvl/Clonetest.htm. Gilbert Meilaender, in testifying before NBAC, pointed out the social importance of children's genetic independence from their parents: "They replicate neither their father nor their mother. That is a reminder of the independence that we must eventually grant to them and for which it is our duty to prepare them." ClONING HUMAN BEINGS, supra note 12 , at 81 .

Even if a constitutional right to clone were to be recognized, any legislation which would infringe unduly upon this fundamental right would be permissible if it furthered a compelling interest in the least restrictive manner possible in order to survive this standard of review. See Lifchez, $735 \mathrm{~F}$. Supp. at 1377. Along those lines, the NBAC raised concems about physical and psychological risks to the offspring, as well as about "a degradation of the quality of parenting, and family if parents are tempted to seek excessive control over their children's characteristics, to value children according to how well they meet every detailed parental expectation, and to undermine the acceptance and openness that typify loving families." ClONING HUMAN BEINGS, supra note 12, at 77. The NBAC also noted how cloning might undermine important social values, such as opening the door to a form of eugenics, or by tempting some to manipulate others as if they were objects instead of persons, and exceeding the moral boundaries of the human condition. Id.

The potential physical and psychological risks of cloning an entire individual are sufficiently compelling to justify banning the procedure. The notion of replicating existing humans seems to fundamentally conflict with our legal system, which emphatically protects individuality and uniqueness. Banning procreation through nuclear transplantation is justifiable in light of common law and constitutional protection of the sanctity of the individual and personal privacy. Francis $\mathrm{C}$. Pizzulli, Note, Asexual Reproduction and Genetic Engineering: A Constitutional Assessment of the Technology of Cloning, 47 S. CAL. L. REV. 476, 502 (1974).

In the United States, couples' constitutional arguments regarding a privacy right or liberty right to use inheritable genetic interventions would appear to be stronger than those regarding access to cloning. In decisions construing the Americans with Disabilities Act, including one before the U.S. Supreme Court, individuals with AIDS were judged to be disabled because their disease was seen as interfering with a major life function-reproduction. Bragdon v. Abbott, 524 U.S. 624, 631 (1998). The argument seems to be that "normal" reproduction involves the creation of children without diseases.

Couples who both have sickle cell anemia or some other recessive genetic disorder might argue that a ban on germline interventions deprives them of reproductive liberty because it is the only way they can have healthy children. (There are several fallacies in that argument. The children born may have other diseases. And the genetic modification intervention itself might harm the children or be ineffective.) Forbidding the use of the techniques, it would be argued, forces them to go childless.

The couple might bolster their argument with a reference to another aspect of the Lifchez holding. The court in that case also held the ban on embryo research unconstitutional because it forbade parents from using experimental diagnostic techniques to learn the genetic status of their fetus. See Lifchez, 735 F. Supp. at 1366-67. The court reasoned that, if the woman has a constitutional right to abort, she has a right to genetic information upon which to make the decision. See id. Using an expansive interpretation, Lifchez could be understood as saying that it was understandable that couples would choose to have only children of a certain genetic makeup and that such a decision was constitutionally protected. However, even if there were a constitutional right to use inheritable genetic interventions, such interventions could be banned if they posed compelling physical, psychological or social risks. To be constitutional, the ban would also need to be nartowly focused to operate in the least restrictive manner possible.

82 See KAISER FAMILY FOUND., Lawmakers Vow 10 Introduce Cloning Restrictions. Bush Signals He Will "Work to Pass" Ban, Kalser Dally RePRod. Health Rep., Mar. 29, 2001, available 
research and reproductive cloning, and this proposal, known as the Weldon bill, has reached the Senate. ${ }^{83}$ When the Senate takes up the issue, it will have to decide whether to agree with the Weldon bill (in which case it will be signed by the President and become law), or to try to craft a bill that outlaws reproductive cloning, but permits research cloning, as recommended by the National Academy of Sciences. In this case, the Senate bill will be sent to a conference committee where, unless the politics of the issue changes radically, it will likely die.84 Of course, unless the United States passes legislation outlawing reproductive cloning, it cannot take any meaningful leadership role in the international treaty area on this issue.

\section{PROMULGATING AN INTERNATIONAL TREATY}

The adoption of an international treaty is the most appropriate approach to prohibit species-altering interventions. A rogue doctor or scientist who wishes to offer the procedure can easily move across borders if a particular nation bans the procedure. When the American physicist Richard Seed announced he intended to clone human beings and U.S. lawmakers threatened to clamp down on the procedure, he responded that he would open up a clinic in Mexico85 or join a Japanese-based project. ${ }^{86}$ Restrictions on European biotechrology companies have stimulated some to move to Africa. ${ }^{87}$

Various international declarations and laws already oppose human cloning or

at http://report.kff.org/archive/repro/2001/3/ kr010329.2.htm.

83 As of June, 2002, the Senate had three bills to consider. S. 790, introduced by Senator Brownback of Kansas, is substantially the same as the Weldon bill passed by the House of Representatives in August, 2001. Human Cloning Prohibition Act, S. 790, 107th Cong. (2001). It would ban both the creation of human embryos by cloning as well as attempts to create a human child by cloning. Id. at $\$ 3 . \mathrm{S} .1758$, introduced by Senator Dianne Feinstein of California bans attempts at human cloning, defined as "asexual reproduction by implanting or attempting to implant the product of nuclear transplantation into a uterus." Human Cloning Prohibition Act, S. 1758, 107th Cong. (2001). It also specifically permits certain activities, including "nuclear transplantation to produce human stem cells." Id. at $\$ 4$. It was slightly modified on May I and reintroduced as S. 2439 with the endorsement of Senator Orin Hatch. 148 Cong. Rec. \$36,633 (2002) Finally, S. 1893, introduced in late January, 2002 by Senator Harkin of lowa would simply ban cloning as defined as "asexual human reproduction by implanting or attempting to implant the product of nuclear transplantation [defined as "introducing the nuclear material of a human somatic cell into a fertilized or unfertilized oocyte from which the nucleus has been or will be removed or inactivated"] into a woman's uterus or a substitute for a woman's uterus." S. 1893, 107th Cong. $\$ 498 \mathrm{C}$ (2002). For more details, see George J. Annas, Cloning and the U.S. Congress, 346 NEW ENG. J. MED. 1599 (2002).

84 The outstanding question is whether abortion politics will permit members of Congress to outlaw so-called reproductive cloning (which they all agree should be done) without also outlawing research cloning (a prohibition included in the Weldon and Brownback bills because some supporters object to any creation of human embryos in the laboratory, and others believe that once created by cloning, it is inevitable that a cloned human embryo will be introduced into a woman's uterus and eventually result in the birth of a cloned child). The slippery slope from research to reproductive cloning is real, of course, but could be made much less likely by adding restrictions to what physicians involved in infertility treatment could do (e.g., no creation or use of cloned embryos by infertility specialists). Three further steps would virtually eliminate the danger: creation of a federal oversight panel that would have to approve any research projects involving the creation of cloned embryos; outlawing the purchase and sale of human eggs (as is done now for organs and tissues for transplant); and outlawing the freezing or storage of cloned human embryos, eliminating the potential for stockpiling human embryos, and making it almost impossible for a research embryo to be used for reproduction in practice. George J. Annas, Cell Division, BOSTON GloBe, Apr. 21, 2002, El.

85 Gene Weingarten, Strange Egg. WASH. POST, Jan. 25, 1998, at F1.

86 Radical Scientist to Help Open Cloning Clinics in Japan, JaPAN SCI. SCAN, Dec. 7, 1998 , available at 1998 WL 8029927.

87 Thomas Hirenec Atenga, Africa: Biotech Firms Have Their Eyes on Africa, Euro MPS Say, INT'L PRESS SERV., Oct. 14, 1998. 
inheritable genetic interventions, either directly or indirectly. As summarized above, 88 many of these existing legal documents have shortcomings. Some are mere moratoria, set to expire in 2003. Some are limited in the type of species-altering technologies they ban, covering only cloning and not inheritable genetic interventions, or even just applying to cloning via a limited range of techniques.

Some of the existing laws have also been outpaced by technology and do not comprehensively ban all forms of reproductive cloning and inheritable interventions. Others are ambiguous as to what they cover. In some cases, potentially relevant laws were adopted more than two decades ago to deal with a different set of technologies and concerns; it is unclear whether their expansive prohibitions will be applied to the newer technologies of reproductive cloning and inheritable interventions. Moreover, many of the existing declarations and laws do not include sanctions. Thus, there is a need for an international treaty to encourage participating nations to clarify what is prohibited and have them commit to effective criminal penalties for breaches.

The treaty we propose takes a strong human rights perspective. This approach comports with international human rights traditions because it conceptualizes medical research issues as human rights matters. ${ }^{89}$ It also comports with people's concerns about cloning and inheritable intervention. For example, in a survey of 2,700 Japanese doctors and academics, ninety-four percent of respondents found cloning to be ethically unacceptable, primarily because it insulted human dignity. 90 In Portugal, the National Ethics Council for Human Sciences deemed human cloning unacceptable due to concerns about human dignity and about the equilibrium of the human race and social life.91 Human rights language is also evident in calls for a prohibition on cloning, such as one by the Council of Europe's Parliamentary Assembly, emphasizing that "every individual has a right to his own genetic identity." 92

Concerns about human cloning run sufficiently deep that even those who would make money on the procedure have come out against it. Ian Wilmut, the scientist whose team cloned Dolly the sheep, might benefit financially if humans were cloned because his group holds a patent on a cloning process. But he has testified around the world against human cloning. ${ }^{93}$ Similarly, BIO (the Biotechnology Industry

88 See supra notes 39 to 56 and accompanying text.

89 BRIT. MED. ASS'N, THE MEDICAL PROFESSION AND HUMAN RUGHTS 205+40 (2001), see also sources cited supra note 32.

90 Mosi Docrors, Academics Oppose Human Cloning, JAPAN ECON. NEWSWIRE, Nov. 7, 1998.

91 Conselho Nacional de Etica para as Ciencias de Vida [National Council on Ethics for the Life Sciences], Opinion on Embryo Research and the Ethical Implications of Cloning, No. 21/CNEV/97 (1997).

92 Resolution on Human Cloning, European Parliament, Jan. 15, 1998, O.J. (C 34) 164 (1998).

93 See Jan Wilmut, Cloning for Medicine, SCIENTIFIC AM., Dec. 1998, at 58:

None of the suggested uses of cloning for making copies of existing people is ethically acceptable to my way of thinking, because they are not in the interests of the resulting child. It should go without saying that I strongly oppose allowing cloned human embryos to develop so that they can be tissue donors.

Id. Wilmut has testified around the world against human cloning. See, e.g., Christine Corcos et al., Double-Take: A Second Look at Cloning. Science Fiction and Low, 59 LA. L. REV. 1041, 1051 (denouncing cloning human beings at 3 talk at Princeton University); Creator of Dolly Stresses Benefits of Further Research on Cloning. DAILY YOMIURI, June 7, 1997, available at 19997 WL 1211052 (advocating a worldwide prohibition against human cloning); Cult in the First Bid to Clone Human. EXPRESS, Oct. 11, 2000, available at 2000 WL 24217743 (responding to a British couple's plan to clone their deceased daughter, stating that "it is absolutely criminal to try this [cloning] in a human."); Curt Suplec, Top Scientists Warn Against Cloning Panic: Recreating Humans Would Be Unethical Experts Say, WASH. POST, Mar. 13, 1997, at A03 (testifying against human cloning before the NBAC). 
Organization, a U.S. trade association of biotechnology companies) opposes human reproductive cloning. 94

Numerous entities have called for an enforceable international ban on speciesaltering interventions. The World Health Organization (WHO) at its fifty-first World Health Assembly reaffirmed that "cloning for replication of human beings is ethically unacceptable and contrary to human dignity and integrity."95 WHO urges member states to "foster continued and informed debate on these issues and to take appropriate steps, including legal and juridical measures, to prohibit cloning for the purpose of replicating human individuals." 96

The European Union's Council of Europe adopted the Council of Europe Protocol, prohibiting the cloning of human beings. Twenty-nine countries have signed the treaty. ${ }^{97}$ Similarly, the European Parliament has adopted a Resolution on Human Cloning. The Resolution indicates that people have a fundamental human right to their own genetic identity. 98 It states that human cloning is "unethical, morally repugnant, contrary to respect for the person and a grave violation of fundamental human rights which cannot under any circumstances be justified or accepted." 99 The Resolution calls for member states to enact binding national legislation banning cloning and also urges the United Nations to secure an international ban on cloning. 100

UNESCO's Universal Declaration on the Human Genome and Human Rights specifically addresses cloning. ${ }^{101}$ Like the treaty we propose, the Declaration is based on "universal principles of human rights."102 The Declaration specifically refers to UNESCO's constitution, which underscores "the democratic principles of the dignity, equality and mutual respect of men."103 Article 11 of the Declaration states, "Practices which are contrary to human dignity, such as reproductive cloning of human beings, shall not be permitted." 104 However, the Declaration does not have an enforcement mechanism. Rather, it calls upon nations and international

94 Press Release, BIOTEChNOLOGY IND. ORG., BIO Reirerates Unequivocal Opposition to Reproductive Cloning: Support for Therapeutic Applications, Nov. 25, 2001, available at http://www.bio.org/newsroom/news.asp. See also Frances Bishop, IJth Annual Bio Conference: Ethical Issues in Genetics Create Challenges for Biotech Industry, 8 BIOWORLD TODAY 112 (1997), available at 1997 WL 11130296.

95 Press Release, W.H.O., WORLd HEALTh ASSEMbly, World Health Assembly States its Position on Cloning Human Reproduction (May 14, 1997), available at http://www. who.int/archives/ inf-pr-1997/en/97wha9.html.

96 W.H.O., WORLD HEALTH ASSEMBLY, 51 st Sess., Ethical. Scientific and Social Implications of Cloning in Human Health, WHA51.10, (1998).

97 1) Croatia, 2) Cyprus, 3) Czech Republic, 4) Denmark, 5) Estonia, 6) Finland, 7) France, 8) Georgia, 9) Greece, 10) Hungary, 11) Iceland, 12) Italy, 13) Latvia, 14) Lithuania, 15) Luxembourg, 16) Moldova, 17) Netherlands, 18) Norway, 19) Poland, 20) Portugal, 21) Romania, 22) San Marino, 23) Slovenia, 24) Slovenia, 25) Spain, 26) Sweden, 27) Switzerland, 28) the former Yugoslav Republic of Macedonia and 29) Turkey. See also AdDITIONAL PROTOCOL (EXPLANATORY REPORT) TO THE CONVENTION ON HUMAN RIGHTS AND BIOMEDICINE, Jan. 12, 1998, available at http//conventions.coe.int/Treaty/en/ Reports/Html/168.htm.

98 Resolution on Human Cloning, Eur. Parliament, Jan. 15, 1998 O.J. (C34) 164 (1998).

99 ld.

$100 \quad I d$.

101 U.N.E.S.C.O., Universal Declaration on the human Genome and Human Rights, 29th Sess., 29 C/Res. 16 (1997), available at http://www.unesco.org/human_rights/hrbc.htm. The declaration was adopted by the General Assembly in 1999. G.A. Res. 152, U.N. GAOR, 53rd Sess., U.N. Doc. A/53/152 (1999).

102 Universal Declaration on the human Genome and Human Rights, Introduction.

103 Id.

104 Id. ant. 11. 
organizations to enact national and international policies to prohibit cloning and to identify and prohibit those genetic practices that are contrary to human dignity. ${ }^{105}$

\section{A. The Process for Creating an INTERnational TrEaty}

On August 7, 2001, France and Germany urged the U.N. Secretary-General to add an International Convention against reproductive cloning of human beings to its agenda. ${ }^{106}$ The French-German initiative is focused on banning only reproductive cloning apparently because there is an international consensus on this issue. It is worth noting that the laws of both countries ban research cloning and other forms of inheritable genetic interventions as well, and that political leaders in both countries have spoken out publicly in favor of imposing a broader ban. Nonetheless, both of these countries seem content to pursue a two-step process at the United Nations: securing as soon as possible a ban on reproductive cloning, and leaving negotiations on other issues, including inheritable genetic alterations and research cloning, for a second round of international negotiations. This may in fact be the only practicable way to proceed.

In November 2001, the Legal Committee of the United Nations added its support to a ban on reproductive cloning, 107 and the first meeting on the treaty was held in February 2002. There was virtual unanimous support for the treaty among the approximately 80 countries that attended, although the United States took the position that it would only support the treaty if it also outlawed research cloning. The issues of reproductive cloning discussed in this Article can, of course, be separated from those involved in research cloning, and will likely have to be if a treaty on reproductive cloning is to be adoptec. ${ }^{n} 8$ Whether the U.S. position will change remains to be seen. It seems likely that this U.N. treaty process is the only way a cloning treaty is likely to be achieved. ${ }^{109}$ The treaty we propose is an attempt to provide language that could be used in both stages of a two stage process, or in one process if they are combined. It is drafted in a way to reflect the broad social concerns against species-altering technologies and to close loopholes in existing legal documents and declarations. Like the U.N. Legal Committee, we believe that the time is ripe for a flat-out international ban on human cloning. We also advocate a similar ban on inheritable genetic interventions.

105 Id.

106 Request for the Inclusion of a Supplementary ltem in the Agenda of the 56th Session. International Convention Against the Reproductive Cloning of Human Beings, U.N. GAOR, S6th Sess., U.N. Doc. A/56/192 (2001).

107 United Nations Calls for a Treaty to Ban Human Cloning, BIRMINGHAM POST, Nov. 21 , 2001 , at 8 .

108 See supra note 84 . The next meeting of the ad hoc committee is scheduled at the United Nations for September 23-27, 2002. It is anticipated that the mandate to guide subsequent treaty negotiations will be adopted at this meeting, and that treaty language may be agreed upon a year or so later.

109 Stephen P. Marks, Tying Prometheus Down: The International Law of Human Genetic Manipulation, $3 \mathrm{CHI}$. J. INT'L L. (forthcoming 2002). The other U.N. treaty method is known as a framework convention, which is used when countries agree that a particular field needs to be regulated (such as the environment), but do not yet agree on the specifics of how the regulation should work. Because there is basic international agreement on human reproductive cloning, the framework convention is inappropriate. See. e.g., Daniel Bodansky, The United Nations Framework Convention on Climate Change: A Commentary, 18 YALE J. INT'L L. 451, 494 (1993). See also ANThONY AUST, MODERn TREATY LAW AND PRACTICE 97 (2000); Donald M. Goldberg, Negotiating the Framework Convention on Climate Chonge, 4 TOURO J. TRANSNAT'L L. 149 (1993); Lee A. Kimball, The Biodiversity Convention: How to Make it Work, 28 VAND. J. TRANSNaT'l L. 763 (1995). 


\section{CONCLUSION}

Biotechnology, especially human cloning and inheritable genetic alteration, has the potential to permit us to design our children and to literally change the characteristics of the human species. The movement toward a posthuman world can be characterized as "progress" and enhancement of individual freedom in the area of procreation; but it also can be characterized as a movement down a slippery slope to a neo-eugenics that will result in the creation of one or more subspecies or superspecies of humans. The first vision sees science as our guide and ultimate goal. The second is more firmly based on our human history as it has consistently emphasized differences, and used those differences to justify genocidal actions. It is the prospect of "genetic genocide" that calls for treating cloning and genetic engineering as potential weapons of mass destruction, and the unaccountable genetic researcher as a potential bioterrorist.

The greatest accomplishment of humans has not been our science, but our development of human rights and democracy. Science cannot tell us what we should do, or even what our goals are, therefore, humans must give direction to science. In the area of genetics, this calls for international action to control the techniques that could lead us to commit species suicide. We humans clearly recognized the risk in splitting the atom and developing nuclear weapons; and most humans recognize the risk in using human genes to modify ourselves. Because the risk is to the entire species, it requires a species response. Many countries have already enacted bans, moratoria and strict regulations on various species-altering technulogies. The challenge, however, is global, and action on the international level is required to be effective.

We believe that the action called for today is the ratification of an international convention for the preservation of the human species that outlaws human cloning and inheritable genetic alterations. This ban would not only be important in itself; but it would also mark the first time the world worked together to control a biotechnology. Cloning and inheritable genetic alterations are not bioweapons per se, but they could prove just as destructive to the human species if left to the market and individual wants and desires.

We think an international consensus to ban these technologies already exists, and that countries, non-governmental organizations and individual citizens should actively support the treaty process, as they did with the recent Convention on the Prohibition of the Use, Stockpiling, Production and Transfer of Anti-Personnel Mines and their Destruction (Land Mine Treaty). ${ }^{110}$

Cloning may not seem as important as landmines, as no clone has yet been born and thus no children have been harmed by this technique. Nonetheless, cloning has the potential to harm all children, both directly by physically and mentally harming them, and indirectly by devaluing all children-treating them as products of their parents' genetic specifications. Likewise, inheritable genetic alteration carries the prospect of developing a new species of humans that could turn into either destroyers or victims of the human species. Opposition to cloning and inheritable genetic alteration is "conservative" in the strict sense of the word: it seeks to conserve the human species. But it is also liberal in the strict sense of the word: it seeks to preserve democracy, freedom and universal human rights for all members of the human species.

110 Convention on the Prohibition of the Use, Stockpiling, Production and Transfer of AntiPersonnel Mines and on their Destruction, G.A. res. 47/39, 47 U.N. GAOR Supp. (No. 49) at 54, U.N. Doc. A/47/49 (1992). 


\title{
APPENDIX
}

\section{LEGISLATION IN FORCE RELATED TO HUMAN SPECIES PROTECTION}

\begin{abstract}
ASIA
Japan

The "Law concerning Regulation Relating to Human Cloning Techniques and Other Similar Techniques," Nov. 2000, in effect since June 2001. English version, available at http://www.mext.go.jp/english/shinkow/index.htm.
\end{abstract}

The Japanese law prohibits the transfer of embryos created by techniques of human cloning, and those created by xenotransplantation. However, it allows the application of these techniques and other similar ones for research purposes as long as the embryo created is not allowed to be transplanted in a human or an animal. It also imposes criminal sanctions.

Guideiines to the "Law concerning Regulation Relating to Human Cloning Techniques and Other Similar Techniques," Dec. 4, 2001, Minister of Education and Science, available at http://www.mext.go.jp/a_menu/shinkou/seimei/2001/hai3/ 17_shishin.pdf (in Japanese).

Commentaries to the Guidelines mentioned above by the Ministry of Education and Science, available at http://www.mext.go.jp/a_menu/shinkou/seimei/2001/hai3/20_ shishin.pdf (in Japanese).

\section{Council of Europe}

\section{EUROPE}

Additional Protocol (Explanaiory Report) to the Convention on Human Rights and Biomedicine, 12 January 1998., available at http://conventions.coe.int/Treaty/EN/ Treaties/Html/168.htm.

Article 1.

Any intervention seeking to create a human being genetically identical to another human being, whether living or dead is prohibited. For the purpose of this article, the term human being 'genetically identical' to another human beings means a human being sharing with another the same nuclear gene set.

Convention for the Protection of Human Rights and Dignity of the Human Being with regard to the application of Biology and Medicine - Convention on Human Rights and Biomedicine; Oviedo, Apr. 4, 1997, available at http://conventions. coe.int/Treaty/EN/Treaties/Html/164.htm.

Article 13. Interventions on the human genome.

An intervention seeking to modify the human genome may only be undertaken for preventive, diagnostic or therapeutic purposes and only if its aim is not to introduce any modification in the genome of any descendants.

\section{Austria}

Federal Law of 1992 (Serial 275) Regulating Medically Assisted Procreation (The Reproductive Medicine Law), and Amending the General Civil Code, The Marriage 
Law and the Rules of Jurisdiction (1993), available at http://www.bmbwk.gv.at/ (in German).

The law does not explicitly prohibit the cloning of human beings, but it limits research on human embryos (defined as "developable cells"). Its central principle is that reproductive medicine is acceptable only within a stable heterosexual relationship for the purpose of reproduction. The law provides that embryos can be used only for implantation in the woman who has donated the oocytes and cannot be used for other purposes. The donation of embryos or gametes is explicitly prohibited.

\section{Denmark}

Act No. 460 on Medically Assisted Procreation in connection with medical treatment, diagnosis and research, June 10, 1997, in force Oct. 1, 1997; and Act No. 503 on a Scientific, Ethical Committee System and the Handling of Biomedical Research Projects.

According to $\$ 28$ (Act No. 460) research with the following aims is forbidden:

a) research where the aim is to develop human reproductive cloning;

b) research where the aim is to facilitate the creation of a human identity by melting together genetically unidentical embryos or parts of embryos before the implantation in the woman womb.

Provision $\S 4$ states that it is forbidden to implant identical unfertilized or fertilized ova in one or more women. The Act establishes penalties of fine and imprisonment for the doctor and the authorized health persons that violate its provisions.

\section{Finland}

Medical Research Act (No. 488/1999).

The legislation applies to embryo research. Section 15 explicitly prohibits any research which has the objective of modifying the germ line, but makes an exception for research done for the purposes of curing or preventing serious hereditary disease.

\section{France}

Law No. 94-653 of July 29 1994, on Respect for the Human Body, available at http://www.cnrs.fr/SDV/loirespectcorps.html (in French).

The law prohibits the invasion into the integrity of the human species, eugenic behaviors intended to organize selection of human beings, and conversion of genetic characteristics leading to any change in descendants of humans (except for studies aiming at prevention and treatment of hereditary diseases) (articles 16-4). The act also amends the Penal Code, prescribing penalties of imprisonment and fine for the implementation of eugenic activities on human beings (Article 511-1).

Law No. 94-654 of July 29, 1994, on the Donation and Use of Elements and Products of the Human Body, Medically Assisted Procreation, and Prenatal Diagnosis, available at http://www.cnrs.fr/SDV/loidocorps.html (in French).

The bioethics legislation and its amendments (Law No. 94-653 and Law No. 94-654) specifically prohibit human cloning, creation of hybrids and chimeras, germline gene 
therapy, the creation of embryos purely for research purposes, and eugenic experiments.

\section{Germany}

Gesetz zum Schutz von Embryonen (Embryonenschutzgesetz), v.13.12.1990 (BGBI. I S.2747) [Federal Embryo Protection Law], available at http://www.bmgesundheit. de/rechts/genfpm/embryo/embryo.htm (in German).

This special criminal law prohibits human reproductive cloning and prescribes criminal penalties (imprisonment or fine) against violations. Regarding germ cells, the act prohibits any artificial changes in the genetic characteristics of human cells and prohibits the use of such altered cells for fertilization.

\section{Hungary}

Law No. 154 (1997) on Genetic Research. The law bans germline engineering.

\section{Iceland}

Artificial Fertilisation Act No. 55/1996, Regulation No. 568 on Artificial Fertilisation Act English version, available at http://brunnur.stjr.is/interpro/htr/htr.nsf/pages/ lawsandregs 0002 .

Art 12(d): "It is prohibited to perform cloning."

\section{Norway}

Law No. 56 of August 51994 on the Medical Use of Biotechnology, (1995) 46 (1), available at http://www.stortinget.no/english/index.html.

Article 3-1 prohibits "research on fertilized eggs."

Ministry of Health and Social Affairs, The Act relating to the Application of Biotechnology in Medicine, 1994.

Prohibits germline therapy and prescribes criminal sanctions for its violation.

Russia

Law on Reproductive Human Cloning, Apr. 19, 2002.

The law establishes a moratorium on human reproductive cloning and the importation of cloned embryos for five years.

\section{Spain}

Law No. 35/1988, Nov. 22, 1988, on techniques of assisted reproduction, available at http://www.geocities.com/Eureka/9068/SANIDAD/reproduc.html (in Spanish), modified by Organic Law No. 10/995 of 23 November 1995, available at http://www. webcom.com/knuzes/legislac09.htm (in Spanish).

The law No. $35 / 1988$ establishes in sections $\$ 13.3(d)$ and $15.2(\mathrm{~b})$ that any therapeutic intervention, investigation or research activity in pre-embryos in vitro, pre-embryos, embryos and fetuses in utero, will be authorized only if such intervention or activity does not alter its genetic make-up (in so far as it does not contain any anomaly), or if it is not aimed to individual or race selection. 
The Organic Law introduced in section II of the Penal Code a Title V: Offenses relating to genetic engineering, prescribing criminal and civil sanctions for its violation.

The Spanish Penal Code (Article 16 1,2) prohibits bringing about the birth of identical human beings as a result of cloning or other procedures aimed at the selection of humans.

\section{Sweden}

Law No.115 of Mar. 14, 1991, Act concerning measures for the purposes of Research or Treatment in connection with Fertilized Human Oocytes (1993). This statute and the in vitro Fertilization law of 1988 govern embryo research. Any research, which seeks to genetically modify the embryo, is prohibited.

\section{United Kingdom}

Human Reproductive Cloning Act 2001, UK Stat. 2001 c23 \&1, in force Dec. 4, 2001.

Makes it an offense for a person to place "in a woman a human embryo which has been created otherwise than by fertilisation."

\section{Israel}

\section{MIDDLE EAST}

Prohibition of Genetic Intervention Law No.5759 (cloning on Human Beings and Genetic Modifications for Reproductive Cells) (1998), available at http://www.knesset.gov.il/index.html.

The law introduces a five-year moratorium on human reproductive cloning and germline engineering and prescribes criminal sanctions for its violation.

\section{Costa Rica}

\section{NORTH AMERICA}

Decree No.24029-S: A Regulation on Assisted Reproduction, Feb. 3, 1995, available at http://www.netsalud.sa.cr/ms/decretos/dec5.htm (in Spanish).

Article 11.

Any manipulation or alteration of an embryo's genetic code is prohibited, as well as any kind of experimentation with embryos.

\section{Australia}

\section{OCEANIA}

Victoria Infertility Treatment Act 2000 - No.37/200 (Amendment of the Act No.37/1997, 63/1995), available at http://www.dms.dpc.vic.gov.au.

The State of Victoria explicitly bans human reproductive cloning and germline engineering, and prescribes criminal sanctions (fines and imprisonment) for its violation. 


\section{Argentina}

\section{SOUTH AMERICA}

Decree No.200/97 of Mar. 7, 1997: A Prohibition on Human Cloning Research, available at http://infoleg.mecon.gov.ar/txtnorma/42213.htm (in Spanish).

Article 1: Cloning experiments regarding human beings are prohibited.

\section{Brazil}

Law No.8974 (1995) on genetically modified organisms, available at http://www.mct.gov.br/legis/leis/8974_95.htm (in Portuguese).

Art. 8 of the law prohibits the genetic manipulation of the germline as well as the intervention on the human genetic material in vivo, with the exception of the treatment of genetic defects.

\section{Peru}

Law No.26842, General Health Law, July 9, 1997, available at http://www.congreso. gob.pe.

Art. 7

"[T]he fertilization of a human ovum with an intent other than procreation is prohibited, as well as human cloning." (Unofficial translation).

Law No. 27636, Criminal Code: Genetic Manipulation.

The genetic manipulation with the purpose of cloning a human being is prohibited. The law establishes criminal sanctions of imprisonment for its violation. 